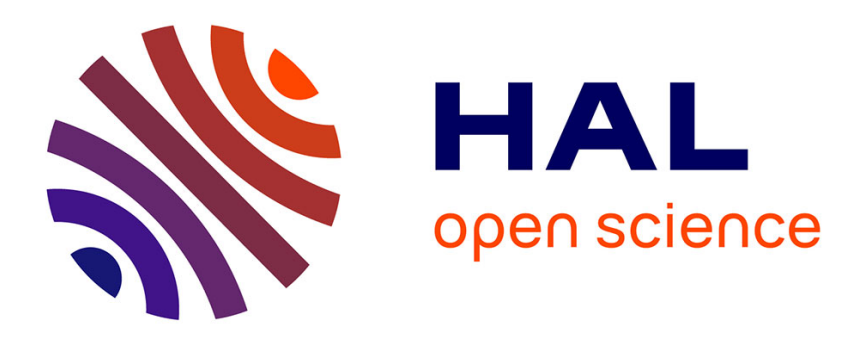

\title{
Inversion of the transverse mode calculation problem in laser resonators
}

\author{
S. Ruschin
}

\section{To cite this version:}

S. Ruschin. Inversion of the transverse mode calculation problem in laser resonators. Journal de Physique IV Proceedings, 1994, 04 (C4), pp.C4-776-C4-776. 10.1051/jp4:19944216 . jpa-00252683

\section{HAL Id: jpa-00252683 https://hal.science/jpa-00252683}

Submitted on 1 Jan 1994

HAL is a multi-disciplinary open access archive for the deposit and dissemination of scientific research documents, whether they are published or not. The documents may come from teaching and research institutions in France or abroad, or from public or private research centers.
L'archive ouverte pluridisciplinaire HAL, est destinée au dépôt et à la diffusion de documents scientifiques de niveau recherche, publiés ou non, émanant des établissements d'enseignement et de recherche français ou étrangers, des laboratoires publics ou privés. 


\section{Inversion of the transverse mode calculation problem in laser resonators}

\section{S. RUSCHIN}

Department of Electrical Engineering-Physical Electronics, Faculty of Engineering, Tel-Aviv University, 69978 Ramat-Aviv, Israel

Instead of calculating the transvetse modal shape for a given resonator configuration, we invert the problem and ask wether a cavity can be designed which supports a given transverse modal structure. This possibility can be advantageous in the design of optical resonators optimized for a given amplifying medium, by matching the geometrical properties of the mode with the gain and saturation profiles of the amplifier. Mode shaping is also of importance when a definite profile is required for the outcoming beam related to a definite application like machining or coupling to a fiber or other device. A formalism was developed based on the Orthogonal Collocation Method. The formalism is based on the expansion of the field in a set of orthogonal functions of number $M$, for which the propagation properties of each of its composing elements are known. Sampling the field at $M$ special points (collocation points) results in the generation of an orthogonal MxM matrix which describes the propagation of a wavefront on a resonator round-trip. By suitable matrix operations, like diagonalization, the fundamental and higher ofder modes are obtained, but more important, the inverse problem can be solved, namely, the synthesis of a suitable optical element of graded transmissivity or reflectivity, which will ensure that the cavity will support a pre-described transverse mode shape. Examples will be given for generating mode patterns by grading the amplitude and/or the phase of mirrors. 